\title{
Inappropriate secretion of antidiuretic hormone associated with cerebellar and cerebral atrophy
}

\author{
D. V. HAMilton \\ M.B., B.Chir., M.R.C.P. \\ Norfolk and Norwich Hospital, Norwich, Norfolk
}

\begin{abstract}
Summary
The syndrome of inappropriate secretion of antidiuretic hormone (SIADH) is described in a 67-yearold man with cerebellar and cerebral atrophy. This is the first reported case of this association.

\section{Introduction}

The syndrome of inappropriate secretion of antidiuretic hormone has been known since 1957 (Schwartz et al.). It is characterized by water retention and a natriuresis with the symptoms of water intoxication. The biochemical features include hyponatraemia, with a concomitant fall in serum chloride, continued renal excretion of sodium, absence of dehydration, and urine osmolality greater than serum osmolality in the presence of normal renal and adrenal function. An example of this syndrome is described in a 67-year-old man with cerebellar and cerebral atrophy.
\end{abstract}

\section{Case report}

A 67-year-old retired thatcher was admitted following a collapse with a period of unconsciousness of about $5 \mathrm{~min}$. On admission the only abnormal physical signs were depressed tendon reflexes. He was confused and occasionally violent. Investigations during the next month revealed a persistently low serum sodium (between 115 and 123 $\mathrm{mmol} / \mathrm{l})$, which improved on fluid restriction (to $129 \mathrm{mmol} / \mathrm{l}$ ), a natriuresis (urinary sodium 256 $\mathrm{mmol} / 24 \mathrm{hr}$ ) and a normal synacthen test. He was discharged in July but was readmitted in October 1975 following two grand mal fits, associated with headaches, nausea and vomiting. There was no abnormality on clinical examination. Serum sodium was $123 \mathrm{mmol} / \mathrm{l}$, chloride $89 \mathrm{mmol} / \mathrm{l}$, and urea 5 mmol/l. A brain scan was normal and an EEG (when the serum sodium was $129 \mathrm{mmol} / \mathrm{l}$ ) was also normal. He soon felt fit and was discharged a fortnight after admission.

In March 1976 he was readmitted for investigation of mental deterioration, personality change, diffculty in walking, nausea and headache. He was slightly ataxic on walking. Hyponatraemia persisted. The cer'ebrospinal fluid was normal. An EEG, recorded when the serum sodium was normal, showed a grossly asymmetrical record with changes compatible with a widespread disturbance in the left hemisphere.

In May 1976 serum sodium was $122 \mathrm{mmol} / \mathrm{l}$, chloride $87 \mathrm{mmol} / \mathrm{l}$, and urea $4.5 \mathrm{mmol} / \mathrm{l}$. Serum osmolality was $240 \mathrm{mOsm} / \mathrm{kg}$, while at the same time his urine osmolality was $820 \mathrm{mOsm} / \mathrm{kg}$, osmolar clearance $0.90 \mathrm{ml} / \mathrm{min}$ (normal range 2-3 $\mathrm{ml} / \mathrm{min}$ ) and free water clearance minus $0.61 \mathrm{ml} / \mathrm{min}$. Urinary arginine vasopressin excretion rate was 79.2 femtomol/1 when serum sodium was 126 $\mathrm{mmol} / \mathrm{l}$, serum osmolality $256 \mathrm{mOsm} / \mathrm{kg}$, and urinary osmolality $795 \mathrm{mOsm} / \mathrm{kg}$. Within a few days of fluid restriction his mental performance improved slightly and serum sodium returned to normal. An air encephalogram revealed a marked degree of cerebellar atrophy and a mild degree of cerebral atrophy.

\section{Discussion}

A number of cerebral causes of SIADH have been described. These include: Infections - meningitis (Nyhan and Cooke, 1956); encephalitis (Rovit and Sigler, 1964); cerebral abscess (Mangos and Lobeck, 1964). Vascular lesions - subarachnoid haemorrhage (Joynt, Afifi and Harbison, 1965); cerebral infarction (Goldberg and Handler, 1960). Inflammatory lesions - systemic lupus erythematosus (Kaplan, Curl and Decker, 1970). Traumatic lesions - head injuries (Haden and Knox, 1965); subdural haematoma (Maroon and Campbell, 1970). Congenital encephalopathies (McCrory and Macaulay, 1957). Neoplasia (Olson, Buchan and Porter, 1969). Acute intermittent porphyria (Perlroth et al., 1966). Guillain-Barré syndrome (Cooper, Green and Wang, 1965).

The mechanism involved in the production of SIADH is thought to be abnormal stimulation of the hypothalamic supraoptic-hypophyseal nuclei or areas of the reticular formation, limbic system or cerebral cortex which have neuronal connections with these nuclei (Olson, Buchan and Porter, 1969).

There have been two other reports of ISADH in the presence of cerebral disease which bear some 
resemblance to the present case. Hagan and Frawley (1970) report SIADH in a diabetic patient on tolbutamide with cerebral atrophy. Normal serum sodium returned on withdrawal of the drug, but hyponatraemia recurred on rechallenge of the patient with tolbutamide and also with chlorpropamide. This complication of sulphonylurea compounds is well known (Darlow, 1977). The role which cerebral atrophy played in the aetiology of this patient's SIADH is difficult to assess. Another report (Peterson and Marshall, 1975) describes SIADH in association with hydrocephalus: the authors postulate that cerebral atrophy and hydrocephalus could be the sequelae of repeated episodes of cerebral oedema from hyponatraemia.

The electroencephalographic changes of SIADH have been reported on several occasions (Epstein et al., 1961). In one report (Schwartz et al., 1969) as in the present case, the most abnormal electroencephalogram was obtained when the serum sodium was normal, while a normal encephalogram was obtained when hyponatraemia was present.

In patients with cerebral and cerebellar atrophy, it must be borne in mind that some of the mental changes and physical signs might be due, in part, to SIADH, treatment of which might improve the patient's clinical state.

\section{Acknowledgments}

I am grateful to Drs J. C. Brown and J. S. Pryor for permission to report this case.

\section{References}

Cooper, W.C., Green, I.J. \& Wang, S. (1965) Cerebral salt-wasting associated with the Guillain-Barré syndrome. Archives of Internal Medicine, 116, 113.

DARLOW, B.A. (1977) Symptomatic hyponatraemia associated with tolbutamide therapy. Postgraduate Medical Journal, 53, 223.

Epstein, F.H., Levitin, H. Glaser, G. \& Lavietes, P. (1961) Cerebral hyponatremia. New England Journal of Medicine, 265, 513.
Goldberg, M. \& Handler, J.S. (1960) Hyponatremia and renal wasting of sodium in patients with malfunction of the central nervous system. New England Journal of Medicine, 263, 1037.

HADEN, H.T. \& KNoX, G.W. (1965) Cerebral hyponatremia with inappropriate antidiuretic hormone syndrome. American Journal of Medical Science, 249, 381.

Hagen, G.A. \& Frawley, T.F. (1970) Hyponatremia due to sulfonylurea compounds. Journal of Clinical Endocrinology and Metabolism, 31, 570.

Joynt, R.J., Afifi, A. \& Harbison, J. (1965) Hyponatremia in subarachnoid hemorrhage. Archives of Neurology, $13,633$.

Kaplan, A.P., Curl, F.D. \& Decker, J.L. (1970) Central hyperventilation and inappropriate antidiuretic hormone secretion in systemic lupus erythematosus. American Journal of Medicine, 48, 661 .

MCCRORY, W.W. \& MaCaulay, D. (1957) Idiopathic hyponatremia in an infant with diffuse cerebral damage. Pediatrics, 20, 23.

Mangos, J.A. \& Lobeck, C.C. (1964) Studies of sustained hyponatremia due to central nervous system infection. Pediatrics, 34, 503.

MARoON, J.C. \& CAMPBell, R.L. (1970) Subdural hematoma with inappropriate antidiuretic hormone secretion. Archives of Neurology, 22, 234.

Nyhan, W.L. \& Cooke, R.E. (1956) Symptomatic hyponatremia in acute infections of central nervous system. Pediatrics, 18, 604.

Olson, D.R., Buchan, G.C. \& Porter, G.A. (1969) The syndrome of inappropriate antidiuretic hormone secretion. Archives of Internal Medicine, 124, 741.

Perlroth, M.G., Tschudy, D.P., Marver, H.S., Berard, C.W., Zeigel, R.F., RechCigl, M. \& Collins, A. (1966) Acute intermittent porphyria. American Journal of Medicine, $41,149$.

Peterson, D.T. \& Marshall, W.H. (1975) Polydipsia and inappropriate secretion of antidiuretic hormone associated with hydrocephalus. Annals of Internal Medicine, 83, 675.

Rovit, R.L. \& Sigler, M.H. (1964) Hyponatremia with herpes simplex encephalitis. Archives of Neurology, 10, 595.

Schwartz, W.B., Bennett, W., Curelop, S. \& BartTer, F.C. (1957) A syndrome of renal sodium loss and hyponatremia probably resulting from inappropriate secretion of antidiuretic hormone. American Journal of Medicine, 23, 529.

Schwartz, B.A., Faye, C., Seguy, M. \& Chretien, J. (1969) An EEG study of water intoxication in the SchwartzBartter syndrome. Electroencephalography and Clinical Neurophysiology, 26, 639. 